\title{
Late Cenozoic Stratigraphy of the Southern Terror Rift, Antarctica: Implications for Tectonic and Climatic Evolution
}

Dhiresh Hansaraj

January 2008

A thesis submitted in partial fulfilment towards the Degree of Master of Science in Geophysics

School of Geography, Environment and Earth Sciences

Victoria University of Wellington 